\title{
Letters
}

\section{Misoprostol in a topsyturvy world}

SIR

In the January 4 issue of the Nerw England Fournal of Medicine three articles appeared on the unapproved use of Misoprostol (Cytotec), which raise an interesting ethical question. The synthetic prostaglandin analogue, Misoprostol, has been successfully used by obstetricians and gynaecologists for a number of years for the induction of a medical abortion in the first or second trimester, for the induction of labour, and for the prevention of postpartum haemorrhages. ${ }^{1}$ Strangely enough the pharmaceutical company which produces and markets the drug, Searle, has never registered its use for these indications with the Food Drug Administration (FDA) or any other agency controlling the safety of drugs. At present the drug is registered by the FDA only for use in the treatment of benign gastric and duodenal ulcerations. The medical representative of Searle $^{2}$ has now issued a warning regarding the unapproved uses (such as its application in obstetrics and gynaecology) of Misoprostol. The company bases its warning on the fact that uterine ruptures have been reported in the literature after administration of Cytotec to pregnant women. There has also been a report of a teratogenic effect of Misoprostol after its use in an unsuccessful attempt to induce an abortion. ${ }^{1}$ This warning by Searle has been seriously criticised by two gynaecologists in an editorial of the New England Fournal of Medicine. ${ }^{3}$
They are especially surprised about the warning since there is so much scientific evidence that the drug is effective and safe when administered during pregnancy. The authors complain that the warning provoked a response from many hospital attorneys, administrators and pharmacists which resulted in an automatic refusal to allow Misoprostol to be dispensed or used. According to the editorial Searle never made any effort to explain its action. In the meantime the American College of Obstetricians and Gynaecologists has notified its members that offlabel (unapproved) use of Misoprostol is justified, if based on sound evidence. In the editorial it is suggested that probably other motives led Searle to its action. A similar opinion can be deduced from a note in the weekly magazine, Time, of January 22 in which Searle is called a "controversyshy manufacturer". ${ }^{4}$

When one considers the situation as described above, I am of the opinion that it is totally impermissible that a pharmacist should refuse to supply Misoprostol to an obstetrician on the basis of Searle's warning. If a pharmacist objects to the abortion, then he should pass the prescription to a pharmacist who is willing to supply the drug for such a purpose.

\section{References}

1 Goldberg AB, Greenberg MB, Darney PD. Misoprostol and pregnancy. New England Fournal of Medicin 2001;344:38-47.

2 Friedman M. Manufacturer's warning regarding unapproved uses of Misoprostol. New England fournal of Medicine 2001;344:61.
3 Hale RW, Zinberg S. Use of Misoprostol in pregnancy [editorial]. New England Fournal of Medicine 2001;344:59-

4 Abortion option [anonymous]. Time 2001 Jan 22: 67.
D O E GEBHARDT PHD Retired biochemist Anna van Burenlaan 1, 2341 VE Oegstgeest
The Netherlands

\section{Measuring quality of life}

SIR

Ravenscroft and Bell's study of endof-life decision making in intensive care $^{1}$ provides valuable evidence for further debate about this ultimate and often subjective, aspect of practice. However, the comment that belated or absent measurement of Quality of Life is "clearly inadequate" ignores the contentious nature of measuring Quality of Life. Another recent review ${ }^{2}$ concludes that Quality of Life cannot be measured either accurately or reliably, and so should not be used as a criterion for health care services.

\section{References}

1 Ravenscroft AJ, Bell MDD. End-of-life decision making within intensive careobjective, consistent, defensible? Fournal of Medical Ethics 2000;26:435-40.

2 Askay A. Can "quality of life" be used as a criterion in health care services? Bulletin of Medical Ethics 2000;162:19-

PHILLIP WOODROW

Practice Development Nurse, Critical Care, East Kent NHS Trust 